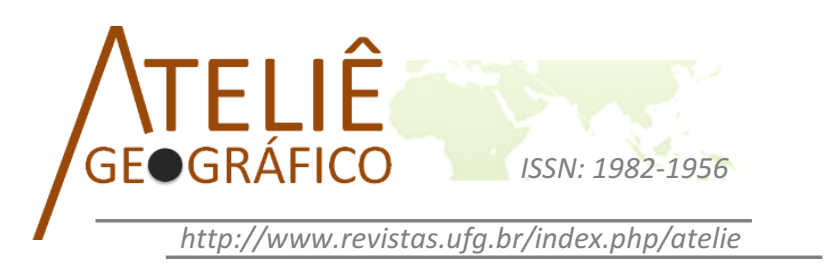

\title{
Fotografia e exploração geográfica: diálogos com Gênesis, de Sebastião Salgado
}

\author{
Photography and geographical exploration: dialogues \\ with Genesis, Sebastião Salgado \\ Fotografía y exploración geográfica: diálogos con Génesis, \\ Sebastião Salgado
}

Lara D'Assunção dos Santos

Universidade do Estado do Rio de Janeiro (UERJ)

larad.assuncao@gmail.com

\begin{abstract}
Resumo
O presente artigo desenvolve-se em torno da relevância das imagens fotográficas na construção de geografias imaginativas e na produção de um forte sentimento de alteridade e nacionalidade. Inicialmente, dissertarei sobre os primeiros registros de espaços inóspitos e como tais imagens faziam parte da cultura da exploração que objetivava deter o conhecimento do mundo. A segunda parte explora brevemente a fotografia do século XX, onde há um imenso potencial de divulgação viabilizado pela imprensa. Na terceira parte, utilizarei o livro Gênesis, de Sebastião Salgado, como referência para pensar a importância de registrar e testemunhar culturas, paisagens e identidades ainda presentes no mundo.

Palavras-chave: Imagem, Fotografia, Sebastião Salgado, Exploração Geográfica.
\end{abstract}

\begin{abstract}
This article develops around the relevance of photographic images in imaginative geographies in the construction and production of a strong feeling of otherness and nationality. Initially, I will discuss about first records of inhospitable spaces and as such images were part of the culture of exploration that aimed to prevent the knowledge of the world. The second part briefly explores the twentieth century photography, where there is a huge potential for disclosure made possible by the press. In the third part, I will use Genesis book, Sebastiao Salgado, as a reference to think the importance of recording and witness the cultures, landscapes and still presents identities in the world.

Keywords: Image, Photography, Sebastião Salgado, Geographical Exploration.
\end{abstract}




\begin{abstract}
Resumen
Este artículo se desarrolla en torno a la relevancia de las imágenes en la construcción de geografías imaginativas y producción de un fuerte sentido de la alteridad y la nacionalidad. Primero hablaré sobre los primeros registros de espacios inhóspitos y cómo estas imágenes eran parte de la cultura de la exploración que tenía como objetivo detener el conocimiento del mundo. La segunda parte explora brevemente la imagen del siglo XX, donde hay un enorme potencial para la divulgación hecha posible por la prensa. En la tercera parte utilizará el libro de Génesis, Sebastiao Salgado, como una referencia a pensar la importancia de la grabación y el testimonio de las culturas y paisajes todavía presentes identidades en el mundo.
\end{abstract}

Palabras clave: Imagen, Fotografía, Sebastião Salgado, Exploración Geográfica

\title{
Introdução
}

Facilmente absorvida dentro da imaginação popular como uma das maravilhas da metade do século XIX, a fotografia representa uma das formas de conceber e habitar o espaço, pois é por meio da imaginação e do imaginário sobre certa entidade geográfica que o espaço ganha materialidade, encarna e passa a existir para nós (LIRA, 2011).

Esta tecnologia permitiu visualizar determinadas partes do globo jamais vistas pelos europeus, mudando radicalmente nossa percepção do mundo e a forma de fazer ciência ao aprimorar a racionalização da visão (LATOUR, 2015), pois tal como o primeiro quadro em perspectiva, as fotografias representaram um marco, uma nova forma de olhar que trazia uma linguagem distinta e universal, colaborando para a construção da paisagem, da identidade e aguçando sentimentos nacionalistas e de alteridade.

O inventário teve início em 1839 através de imagens feitas com daguerreótipo e, posteriormente pela máquina fotográfica. Importante ferramenta de divulgação da cultura de exploração1, o processo fotográfico colaborou para a construção de um imaginário geográfico que trouxe a permanência de uma visão maravilhosa sobre o mundo extra-europeu.

Tendo como base a cultura da exploração, a primeira parte desse trabalho abordará os registros de espaços inóspitos feitos durante as explorações geográficas quando do surgimento do daguerreótipo. Neste período a invenção e o desenvolvimento da fotografia coincidiam com a expansão extraordinária do Império Britânico para alémmar. Além de divulgar as ditas culturas não-ocidentais que se encontravam fora do território europeu, as imagens traziam um discurso de superioridade em relação às demais etnias, pois as primeiras fotografias - vistas como uma representação exata,

\footnotetext{
${ }^{1}$ A definição de cultura da exploração aqui utilizada baseia-se em Felix Driver (2003), onde o autor a define como "variedade de práticas presentes na produção e consumo das viagens de exploração, dentre elas, as práticas 'reprodutivas', por estarem ligadas à transmissão de conhecimento".
} 
uma imitação potencialmente infinita da realidade - apresentavam o Outro como ser exótico, produzindo, assim, um sentimento de alteridade e ao mesmo tempo um sentimento de nacionalidade e identidade, uma vez que reunia todos os povos ditos ocidentais.

A segunda parte do presente texto abordará o trabalho da fotografia do século $\mathrm{XX}$, onde o fotógrafo passa a ser visto como mediador cultural e seu olhar fará toda diferença no momento do disparo. Aqui já existem estudos mais elaborados que veem a fotografia como o resultado da vivência do fotógrafo e, portanto, uma imagem que contém uma assinatura, repleta de significado cultural, que requer um estudo mais minucioso. O elemento fundamental deste trabalho é convidar o leitor a apreciar as fotografias como artefatos conotativos e não denotativos. As fotografias constituem metonímias visuais que brincam com as escalas de mundo (SONTAG, 2004) e, de acordo com os escritos de Vilém Flusser (2011), decifrá-las implicaria, entre outras coisas, no deciframento das condições culturais.

Na terceira parte, utilizaremos o livro Gênesis, de Sebastião Salgado, produzido em 2013. Passados mais de 170 anos desde a invenção do processo fotográfico, a obra do fotógrafo brasileiro é lançada num momento em que praticamente tudo foi fotografado, ou pelo menos assim parece. Já afirmava Susan Sontag no final dos anos 70 que o resultado mais admirável da atividade fotográfica é nos dar a sensação de que podemos reter o mundo inteiro em nossa cabeça - como uma antologia de imagens (SONTAG, 2004). Segundo o autor, Gênesis representa uma homenagem à Terra. Mas, se tudo já foi registrado e nada é novo aos nossos olhos, qual seria a importância dessa obra? O que há de extraordinário em (re)ver etnias, animais e natureza supostamente intocada?

Para iniciar a discussão faz-se primordial expor a importância das imagens para a ciência geográfica à luz da história da fotografia contextualizando os registros feitos de outras culturas como forma de evitar a naturalização do ato de fotografar. Conforme veremos adiante, ao longo dos séculos a fotografia deixará de ser vista como verossimilhança para representar o processo de desencantamento do mundo (BRIZUELA, 2012), quando nada mais seria novo aos nossos olhos. Isto não significa dizer que as fotografias não devem ser debatidas, pelo contrário. Nesse momento, nos apropriaremos da obra Gênesis, de Sebastião Salgado, - que gira em torno de termos caros à ciência geográfica - para reiterar o valor de problematizarmos as imagens, vendo-as como textos a serem decodificados (COSGROVE, 2008).

\section{Explorações geográficas e a imagem como testemunho}

Antes mesmo do daguerreótipo e do instantâneo, os mapas medievais, como por exemplo, as imagens cartográficas $\mathrm{T}-\mathrm{O}$, eram a forma de representação que trazia a visão dos viajantes europeus sobre o mundo ecúmeno não-cristão. A divisão do mundo era dual, excludente, os lugares ocupados por essa sociedade não-cristã eram representados nos mapas por signos que remetiam a heresia, ao profano, ao pecaminoso 
(BORGES, 2008). Quando os cartógrafos não tinham conhecimento geográfico nem cartográfico para produzir mapas mais precisos ${ }^{2}$, a fantasia sobressaía, e os adornos de figuras desenhadas com uma precisão fantástica em meio a continentes ainda não desvendados (DRIVER, 2003) predominavam. Essa geografia fabulosa ${ }^{3}$ presente nos mapas trazia uma proporção inversa entre a quantidade de arte exibida e a quantidade de informação transmitida (ALPERS, 1999).

Apesar de abstratos, os mapas eram mais precisos do que a pintura e o desenho que, embora carregados de subjetividade (BRIZUELA, 2012), possuíam a importante missão de descrever as paisagens4 numa época em que faltavam termos técnicos para exprimir diferentes relevos, rochas e vegetação (CLAVAL, 2004). No período das grandes navegações a geografia fabulosa, descrita por Joseph Conrad como uma fase de especulações extravagantes, deu lugar à geografia militante, caracterizada pela busca do conhecimento empírico a partir das viagens de exploração (DRIVER, 2003), dando início ao choque do imaginado com o empírico (ALLEN, 1971).

Criado no século XIX, o daguerreótipo foi a ferramenta predecessora do instantâneo (BORGES, 2008). Suas imagens auxiliaram na complementação dos mapas, ou seja, no preenchimento dos espaços em branco. As imagens feitas a partir de um daguerreótipo não eram reprodutíveis e sua divulgação era baixa. Essa característica garantiu seu sucesso inicial por parte da elite que emoldurava as imagens em estojos valiosos (MAYA, 2008), mas também significou seu declínio aproximadamente uma década e meia depois da sua invenção, quando o instantâneo passou a predominar por conta de sua facilidade de reprodução.

Algumas imagens feitas com daguerreótipo foram reunidas no primeiro volume de Excursions Daguerrienes: Vues et monuments les plus remarques du globe, [Excursões daguerrianas: as paisagens e os monumentos mais notáveis do mundo] um álbum de gravuras realizado por leigos publicado em Paris por Natal Paymal Lerebours entre 1841 e $1843^{5}$. A década de 1850 foi a grande era do orientalismo fotográfico: Maxime Du Camp, ao fazer uma grande viagem pelo Oriente Médio em companhia de Flaubert, entre 1849 e 1851, concentrou sua atividade fotográfica em colossos, templos e

\footnotetext{
${ }^{2}$ Apesar das diferenças de tipo, havia uma aura de conhecimento que os cercava, independentemente de sua natureza ou grau de precisão, que conferiu prestígio e poder aos mapas enquanto imagem. Eles permitiam ver algo que de outro modo seria invisível (ALPERS, 1999, p. 262-263).

${ }^{3}$ Termo utilizado por Joseph Conrad em artigo publicado na revista National Geographic, em 1924, para caracterizar as especulações extravagantes próprias da época que nada tinham que ver com ir em busca da verdade.

${ }^{4}$ A invenção da paisagem, segundo Marc Besse, implicou no reconhecimento das sociedades e dos indivíduos enquanto pertencentes a uma localidade, a um território. Tal reconhecimento foi facilitado devido à produção e reprodução de imagens, uma vez que a paisagem traduz visual e imaginariamente a promoção da geografia como discurso específico (BESSE, 2006 p. 23).

Informação presente no site do Musée Français de la Photographie. http://expositions.museedelaphoto.fr/mod_webcms/content.php?CID=LQ1673C [Acesso em julho de 2015].
} 
não na vida cotidiana dos félas ${ }^{6}$ (SONTAG, 2004, p. 105). O Excursions Daguerriennes permitiu ao homem comum correr o mundo e fotografá-lo, tornando-se a versão moderna das excursões geográficas coloniais. Uma vez que sua evolução deu origem ao que hoje conhecemos como fotografia, o daguerreótipo mudou para sempre o conceito de representação, pois contava com mais objetividade do que as pinturas e litografias devido ao seu realismo e sua capacidade de imitação.

O maquinário fotográfico era composto por vários quilos de material, fazendo da viagem uma incômoda tarefa. Todavia, os resultados foram a ampliação e a popularização das possibilidades da viagem estática, que trazia o mundo para dentro de casa (BRIZUELA, 2011) tornando possível viajar através de cópias exatas de objetos distantes. As reproduções fotográficas dessacralizaram a obra de arte, isto é, aboliram a aura dos objetos artísticos como únicos (MAYA, 2008). Desenhos e litografias estavam inseridas na arte subjetiva, enquanto a fotografia passou a fazer parte da ciência, transformando a maneira pela qual o conhecimento geográfico foi construído. A fascinação pelo desconhecido foi suprida de forma mais contundente a partir delas, sobretudo se atreladas aos mapas.

Desta forma, as imagens de mundo não nos parecem mais construções fantásticas, e sim a realidade reproduzida de maneira fiel que tinha como objetivo propagar o mundo tal como ele é. Tanto a fotografia quanto a cartografia compartilhavam a habilidade de capturar e reduzir o mundo a duas dimensões. $\mathrm{Na}$ verdade, a fotografia foi inicialmente referida na ciência geográfica para esse potencial, como técnica de apoio à cartografia (RYAN, 1998).

Uma vez regularizado e miniaturizado, o mundo bidimensional podia ser visto de forma imaginativa e assim, facilmente explorado e dominado. Por seu elevado poder de persuasão, à fotografia foi dada uma gama de papéis, como: ferramenta de exploração, inspetora da paisagem, testemunho de campanhas militares, metodologia da ciência racial, tecnologia de propaganda e educação, entre outros. Esta ferramenta passou a ser acoplada ao discurso geográfico e ao desenvolvimento da ciência geográfica como raison d'être da exploração e da conquista do espaço (RYAN, 1998). Para James Ryan, fotografar o mundo significava compreendê-lo e também controlá-lo (RYAN, 2005).

As relações entre processo colonial e exploração geográfica ficaram mais estreitas durante a segunda fase do colonialismo, sobretudo a partir de 1870 até a Segunda Guerra Mundial (RAMÓN \& NOGUÉ, 1999). Durante os séculos XIX e XX a ideia de exploração era um poderoso método para adquirir conhecimento sobre outras partes do mundo, uma vez que estava carregada de múltiplos significados associados à ciência, literatura, religião, comércio e império. As explorações geográficas atreladas às imagens elevou seu poder de persuasão ao trazer relatórios compostos de daguerreótipos,

\footnotetext{
${ }^{6}$ Homem de casta inferior entre os egípcios e que se ocupa dos trabalhos mais rudes. Fonte: [http://www.priberam.pt/dlpo/fel\%C3\%A1 ]Acesso em janeiro de 2016.
} 
litografias e, posteriormente fotografias - notoriamente após os anos de 1850 - que enriqueciam a literatura.

Os exploradores não só superavam distâncias como também popularizavam mitos e fantasias sobre o mundo não europeu e, por conseguinte, as geografias imaginativas (SAID, 2007 [1978]) impulsionadas pelas imagens. As fotografias feitas pelos europeus fixavam-se na imaginação, servindo para manter os valores culturais, as crenças sociais e as relações políticas dos discursos colonialistas e orientalistas (SCHWARTZ, 1996; RYAN, 1998).

Neste momento, as fotografias eram basilares por promover uma apropriação imperial "leiga" (BRIZUELA, 2011), já que as explorações eram realizadas por amadores destreinados que iam de colecionadores de plantas à oficiais da marinha (DRIVER, 1998). Suas atitudes e premissas constituíam um imperialismo simbólico e não oficial que definia termos culturais e estreitavam as relações políticas entre colonizadores e colonizados (DRIVER, 1992 apud RAMÓN \& NOGUÉ, 1999). A fotografia criou um império paralelo dentro do rol de discursos da época, incluindo ciência, arte, comércio e governo (RYAN, 1998). Não por acaso, neste período de máxima expansão colonial europeia foram criadas revistas, fundações e sociedades como a Société Asiatique, a Royal Asiatic Society, American Oriental Society e também as Sociedades Geográficas.

As fotografias de viagem tornaram-se símbolo desse momento da expansão territorial dos estados centrais em direção aos países que ofereciam mercado, mão de obra e matéria-prima. Elas representavam, portanto, a expansão imperial, o desenvolvimento colonial e o conhecimento científico consistindo em um instrumento cultural que ajudou a estabelecer e afirmar identidade nacional, estimulando o patriotismo e reforçando o senso de lugar no mundo (SCHWARTZ, 1996).

O progresso da civilização ocidental e a superioridade militar, industrial, tecnológica e cultural foram reiterados através das imagens. Por trás das fotografias aparentemente neutras havia um projeto nacional atrelado ao imaginário social. Manifestado tanto no nível individual quanto no coletivo, podendo ser entendido como força transversal presente no pensamento social que direcionam o comportamento da sociedade (HIERNAUX, 2006 apud NOGUÉ, 2012), o imaginário alimentado pelas imagens de expedições geográficas, como as "travel photographs" tinha uma forte carga ideológica, ainda que algumas fotografias apresentassem apenas a topografia local.

Os viajantes ocidentais retratavam o mundo segundo suas visões, possibilitando estudos sobre os "tipos de raça", o conhecimento dos espaços e de seus habitantes para melhor dominar. A intenção era identificar, ordenar, categorizar de forma objetiva os habitantes nativos das terras imperiais, reforçando a superioridade cultural europeia, elemento-chave para justificar seu papel colonial (SCHWARTZ, 1996). O fotógrafo, indivíduo que transita por diferentes territórios geográficos, conseguia inicialmente com muito custo, observar e registrar o mundo, mesclando diferentes culturas com a sua própria. De acordo com Vilém Flusser, os movimentos de um fotógrafo, sobretudo o 
viajante fotógrafo, assemelham-se ao movimento de caça, espreitando a floresta densa da cultura (FLUSSER, 2011).

Com facilidade de reprodução, a fotografia passa a corroborar mais com os espaços discursivos imperialistas ligados ao conhecimento do mundo do que com a arte ${ }^{7}$, uma vez que era tida como sinônimo de verdade. Na passagem do século XIX para o século XX, as imagens impressas em revistas de grande circulação se mostraram importantes fontes de divulgação de ideias, valores e conceitos que integraram o imaginário nacional (BAITZ, 2005).

A revista The National Geographic Magazine, lançada em 1888 pela National Geographical Society ${ }^{8}$, após uma forte crise, mudou seu slogan para "What they want to know" e passou a preencher seus números com mapas mais coloridos para facilitar a compreensão por parte do público leigo e também com fotografias. A entrada deste último recurso em sintonia com a pretensa imparcialidade científica das matérias dava a impressão de precisão (BAITZ, 2005), fator que resultava em maior sentimento de pertencimento a um território. Isso acontecia porque essa revista trazia imagens de localidades jamais vistas para dentro dos lares.

Sendo assim, em termos gerais, a imagem que temos do mundo foi tecida com o auxílio da geografia, haja vista que conceitos como território, fronteira, região, império e nação não são naturais, mas sim, poderosos fundamentos espaciais pré-estabelecidos de acordo com os interesses dos Estados com os quais nos acostumamos a visualizar o mundo.

\section{Fotografia e imaginação geográfica}

As viagens fotográficas do século XIX e início do XX traziam imagens que faziam uma "ponte" entre o real e o imaginado estabelecendo uma memória e uma identidade cultural europeia que passou a ser mais coesa. Deste modo, o surgimento da fotografia foi providencial, pois implicou em visionar o espaço de uma forma diferente, mesmo que nas primeiras expedições científicas ela ainda se mostrasse por demais ligada aos mapas. Este fato deve-se, principalmente, à sua capacidade inicial de imitação exata. Sua suposta representação do real a aproximava da espacialização que não requeria, em princípio, nenhuma interpretação, tal como nos mapas (BRIZUELA, 2012).

Para pensar e elaborar concepções sobre o espaço faz-se necessário construirmos imagens sobre o mesmo, incorporando e reconstruindo o real. Eis aqui a importância da obra de Edward Said, Orientalismo (1978): compreender a ideia de 'alteridade' significa incluir a noção de espacialidade, pois o Outro é para 'nós' uma

\footnotetext{
${ }^{7}$ Há uma crise inicial acerca da natureza da fotografia. Uns a concebiam com uma técnica precisa e exata que permitiria ao homem moderno realizar seu sonho de conquista e domesticação da natureza e outros a tinham como uma estética nova que revolucionaria o mundo das artes (BORGES, 2008, p. 39).

${ }^{8}$ Entidade privada fundada por ocupantes de cargos públicos ou com notória influência em assuntos do Estado.
} 
entidade externa, já que vive em outro lugar. Há, então, uma dimensão espacial inerente na construção do Outro (RAMÓN \& NOGUÉ, 1999). Os espaços coloniais são produtos históricos engendrados a partir dos discursos que, por sua vez, eram baseados nas imagens.

Os séculos XIX e principalmente o XX devido ao aprimoramento nos métodos de reprodução foram preenchidos por fotografias que estimulavam o imaginário europeu. A construção fotográfica do Império Britânico operou em diversos níveis - como símbolo da exploração e de levantamento de dados, como "arte", como testemunho de "progressos" e como símbolo de memórias pessoais (RYAN, 1998). As fotografias do Egito antigo e o discurso Orientalista da época contribuíram para a formação de geografias imaginativas, isto é, representações de lugares, espaços e paisagens que estruturam o entendimento de mundo das pessoas e moldam suas ações (DRIVER, 2005).

Assim, as viagens fotográficas aguçaram as geografias imaginativas das famílias abastadas e, ir ao Oriente representava, naquele momento, um diferencial social (BORGES, 2008). A cor da pele, um dos fatores que distinguia os europeus dos orientais, fazia parte do imaginário dos ocidentais que justificavam a maior pigmentação devido à intensidade do sol que era mais presente naquelas terras. O trópico tornou-se o lar da fotografia, seu habitat natural e também o lugar do exótico ${ }^{9}$, da fantasia e do desejo, de uma natureza desregrada e indomável, não sendo por acaso que a fotografia tenha feito aí uma de suas primeiras aparições (BRIZUELA, 2011). Vale ressaltar que as imagens fotográficas e a visão de mundo por elas criada não foram produzidas de forma isolada, mas interagindo com outros meios, como os relatos de viagem, a cartografia e a pintura. (RYAN, 1998).

As imagens feitas à época perpassam por um exótico distante onde há as primeiras tentativas de presença etnográfica como informação, ainda que bastante contaminada pelo exotismo (TACCA, 2011). Em muitos casos, os traços culturais observados que fogem ao padrão dos viajantes são qualificados como fora de lugar exatamente porque não podem ser lidos a partir de seus códigos culturais. Sendo assim, os qualificam como primitivos, bárbaros ou algo equivalente.

No caso brasileiro, Natália Brizuela em sua obra "Fotografia e Império: paisagens para um Brasil moderno" narra o desenvolvimento de uma imaginação geográfica e do um sentimento de nacionalidade através das fotografias feitas aqui no século XIX. Associada à arte da cartografia, as fotografias ajudaram a elaborar um inédito "Atlas do Brasil" para o moderno Estado-Nação. A construção de um projeto nacional foi impulsionada através dos desenhos feitos pelos viajantes que visitaram o território nacional entre o final da década de 1810 e a década de 1830 , como também

\footnotetext{
${ }^{9}$ Vale salientar que Natália Brizuela destaca em seu "Fotografia e Império" que Daguerre, o inventor do daguerreótipo - precursor da máquina fotográfica - colocava Espanha, Itália e África como o Oriente da França e da Europa.
} 
com a ajuda de milhares de fotografias que tornavam visível a pátria desconhecida (BRIZUELA, 2011).

Outro fator de grande importância para a configuração da imaginação geográfica brasileira foram os romances indianistas do século XIX (BRIZUELA, 2011) que faziam referência à idealização do indígena, por vezes retratado como um mítico herói nacional. A visualização do Brasil divulgada por esses escritores requeriam um deslocamento, ainda que imaginário, pelo território brasileiro.

Destarte, nos estudos do antropólogo Fernando Tacca (2011) sobre as primeiras imagens feitas de índios, constata-se que o indígena tem uma representação muito pequena e quase imperceptível durante todo o século XIX. As fotografias realizaram-se na França porque ocorria à época alguns eventos científicos onde os índios seriam apresentados. Trata-se de um conjunto de 5 daguerreótipos de um grupo de índios pertencentes a uma tribo então denominada Botocudo. Depois da discussão acadêmica, a decodificação do exótico: apalpados, medidos e enquadrados nos cânones do discurso institucional da antropologia física, além de registrados pela Sociedade de Geografia.

Assim eram formadas imagens de mundo com o intuito de forjar uma determinada realidade que facilitasse alguns discursos predominantes no século XIX, como por exemplo, o da superioridade da raça branca e a incapacidade dos povos não europeus, classificados como primitivos e selvagens. Em 1880, com o surgimento do instantâneo e seu uso massivo, Marc Ferrez levou um grupo de índios bororo para um estúdio e produziu uma imagem domesticada do selvagem, circunstanciado pela encenação fotográfica (TACCA, 2011). A natureza e o habitat deixam de ser importantes, são representações, um pano de fundo para a imagem. $O$ índio do final do século XIX é ainda exótico, porém, domesticado.

No século seguinte, o índio deixa de ser um ente contraditório ao sentido moderno da fotografia, para permear as fronteiras entre o etnográfico e o nacional. $\mathrm{O}$ fotojornalismo moderno no Brasil feito pela revista "O Cruzeiro" e o apoio da Comissão Rondon ${ }^{10}$ aumentaram significativamente a importância do índio como símbolo de nosso país.

Em suma, as imagens fotográficas além da função clássica documental, podem ser vistas como dados que informam sobre a forma simbólica e atribuem significados às representações e ao imaginário social. A fotografia não apenas revelaria a imagem per se, mas desvelaria as condições culturais e a assinatura do fotógrafo no tocante aos seus principais interesses, que nos casos demonstrados, permeavam o enaltecimento daquilo que lhe parecia exótico.

\footnotetext{
${ }^{10}$ A partir de 1890 o governo instaurou uma série de comissões para implementar linhas e postos telegráficos pelo interior do país que contribuiu para a ocupação de uma parte ainda desconhecida do território brasileiro, além de defender as fronteiras nacionais. Fonte:[ http://povosindigenas.com/comissao-rondon] Acesso em julho de 2015.
} 


\section{Sebastião Salgado em Gênesis: reolhares sobre antigas rotas}

Sebastião Salgado, economista nascido em Aimorés (MG), saiu de sua terra natal nos anos de 1970, fugido da ditadura militar e atualmente é radicado em Paris. Consagrou-se como fotógrafo-documentarista por suas obras renomadas tais como Outras Américas (1986), em que retratou pobres latino-americanos, Exodos (2000), onde ele voltou a atenção para o fenômeno global de desalojamento em massa de pessoas e Trabalhadores (1996), obra em que o fotógrafo revela as condições de trabalho inumanas ao redor do mundo. Sebastião Salgado recebeu praticamente todos os principais prêmios de fotografia do mundo como reconhecimento por seu trabalho. Após anos sem fotografar, desanimado e desesperançoso da raça humana, o fotógrafo retoma suas atividades com o livro Gênesis (2013) que o permitiu viajar por oito anos ao redor do mundo.

Em consonância com as discussões expostas nos tópicos anteriores, exporemos Gênesis (2013) a partir da ideia de fotografia como material a ser desvelado, ou seja, desvinculando-a da verossimilhança inerente à ferramenta fotográfica desde sua invenção. Tudo o que a câmera registra é um desvelamento - quer se trate de algo imperceptível, partes fugazes de um movimento ou apenas de um modo elíptico de ver (SONTAG, 2004). Faz-se necessário, então, investigar as condições culturais e as circunstâncias históricas as quais foram elaboradas (RYAN, 1998). Sendo assim, consideramos que as imagens fotográficas não falam por si mesmas ou mostra-nos o mundo através de olhos inocentes, afinal, segundo Susan Sontag (2004), tirar fotos serviria para desvelar uma verdade oculta e também para conservar um passado em via de desaparecer.

Partindo dessa percepção, podemos iniciar citando a massiva presença de fotografias de natureza em Gênesis, que aparece como protagonista na obra do fotógrafo brasileiro. De acordo com os relatos presentes em seu livro biográfico "Da minha terra à Terra" (2014) e no documentário vencedor do festival de Cannes "O Sal da terra" (2015) a provável causa para que ele fizesse tal escolha deve-se à devastação da Mata Atlântica do Vale do Rio Doce, em Minas Gerais, sua terra natal.

A rápida transformação por qual passou a fazenda em que foi criado e onde ainda vive seu pai o impulsionou a fundar juntamente com sua esposa, Lélia Wanick Salgado, o Instituto Terra ${ }^{11}$. Desde 1998, quando de sua fundação, eles puderam testemunhar o crescimento das mudas e o gradual retorno das espécies locais. $\mathrm{O}$ fotógrafo, então, sentiu-se na incumbência de registrar o poder de resiliência das paisagens culturais.

Como forma de pensar acerca dos registros de Sebastião Salgado em Gênesis, levarei em consideração as ideias que sempre permearam os registros fotográficos, isto é,

\footnotetext{
11 Para maiores informações acesse: [http://www.institutoterra.org/pt_br/conteudosLinks.php?id=22\&tl $=\mathrm{UXVlbSBzb} 21 \mathrm{vcw}==\& \mathrm{sb}=\mathrm{NQ}==\# . \mathrm{V} 4 \mathrm{u}$ SBvkrLIV ] Acesso em Julho de 2016.
} 
fatores que impulsionavam a captura. A priori, destaco a escolha de Salgado em não fotografar a Europa sob a justificativa de que se trata de um continente deveras modificado. Certamente tal lógica o aproxima daquela utilizada pelas tropas imperiais: ambos tiveram como ponto de partida o continente europeu sem registrar o que está nele, afinal, o intuito era mostrar aquilo que era estranho aos olhos.

Levando-se em consideração o longo tempo de viagem de Sebastião Salgado para elaborar sua obra poderíamos, de certa forma, compará-lo aos exploradores geográficos. A jornada de Salgado assemelha-se a das tropas imperiais que fotografavam os trópicos e seu exotismo e também à rica tradição dos trabalhos de campo, das expedições territoriais e dos relatos de viagem do século XIX. Tais explorações consistem em verdadeiras metáforas das antigas, o que muda são as novas formas de olhar, de relacionar, de conceber.

Nesse sentido, Gênesis fornece-nos elementos que capacitam entender a fotografia como um poderoso instrumento crítico de decodificação e de visualização de imagens na contemporaneidade. Suas fotografias são testemunhos de grupos sociais que sobreviveram à transformação da natureza em mercadoria operada pelo capitalismo, ampliando assim, o campo de percepção da geografia. A altíssima qualidade das imagens nos desloca para dentro do ambiente em que foram realizadas, colocando-nos como testemunhas coniventes com as grandes mudanças globais.

A aventurosa atividade exploratória do fotógrafo pode ser comparada também com a cultura da exploração vivida nos séculos XVIII e XIX: sua jornada de oito anos, partindo de Paris para Galápagos o aproxima, por exemplo, da viagem científica do naturalista e evolucionista britânico Charles Darwin que a bordo do Beagle iniciou uma jornada de quase cinco anos trazendo novas questões para a ciência, como a teoria da seleção natural.

Outro ponto de destaque encontra-se nos motivos que os moveram a viajar. Se durante a 'época de ouro' da Geografia, a geografia Militante, havia um anseio para a descoberta de outro mundo, após as expedições, a tendência era o fechamento irreversível dos espaços abertos e o fim do heroísmo destemido. O desencantentamento do mundo característico da terceira Era geográfica descrita por Joseph Conrad, a Geografia Triunfante (CONRAD, 1924 apud DRIVER, 2003), teria dado lugar à Era dos viajantes modernos que estariam condenados a fazer suas descobertas em trilhas já exploradas (DRIVER, 2003), algo que pode ser traduzido como o olhar do turista que conhecemos hoje, um olhar colonizado por imagens já vistas viajando para ver o que já se conhece (LISSOVSKY \& MARTINS, 2013). As forças da modernização teriam banido as condições autênticas da exploração. Se nada mais é estranho aos nossos olhos seria possível manter a vivacidade do heroísmo das expedições geográficas após a descoberta quase completa do mundo?

Um traço da vivacidade do heroísmo que ainda encontra-se presente na atualidade e que é perceptível nos registros de Sebastião Salgado, é o heroísmo da visão. Para Susan Sontag (2004), esse heroísmo encontra-se no esforço da captura a qualquer 
preço em termos de paciência e desconforto. O momento apropriado para disparar o obturador requer espera, pois a cada registro haveria uma tentativa de ver as coisas de um modo novo (sobretudo aquilo que todos já viram).

Segundo o próprio Sebastião Salgado, seu objetivo era "captar o mundo que está desaparecendo, uma parte da humanidade que está prestes a acabar, mas que, no entanto, ainda vive, de muitas maneiras em harmonia com a natureza" (SALGADO, 2013, p. 8). Fotografar, desde sua criação, há mais de 150 anos, sempre representou uma técnica que visava apropriar-se do mundo objetivo, contudo, como se sabe, mudanças drásticas nos instrumentos, nas pretensões e nos sentidos ocorreram ao longo desses anos.

Visto que as fotografias no século XIX aguçaram os sentimentos de identidade, nacionalismo e alteridade, nos séculos XX e XXI, o processo foi o inverso: em vez de aglutinar, o boom de imagens resultou em uma forte inclinação a favor da disjunção e da ruptura. Os meios de comunicação sofisticados, instantâneos e globais tendem a promover a desconstrução de significados estáveis amparados, tornando os significados culturais cada vez mais fragmentados e voláteis (COSGROVE, 1994). Se, naquele tempo, os primeiros registros de paisagens representavam a aventura colonialista atrelada ao desafio masculino, no século XX, a mesma paisagem passa de lugar de investigação à urgência de preservação ambiental (COSGROVE \& DELLA DORA, 2008). Sendo assim, o intuito de Sebastião Salgado - diferentemente dos exploradores geográficos do século XIX - não consistiria apenas em perenizar nossa existência, mas também relatar o que sobreviveu após anos de destruição promovida pelo capitalismo desenfreado.

As imagens de etnias mirando a câmera ou em meio aos rituais ciclicamente repetidos presentes em Gênesis se assemelham aos primeiros registros feitos aqui nos trópicos (vide a imagem abaixo), evidenciando que os "novos mundos" da atualidade fotografados por Sebastião Salgado não foram construídos por terras nunca visitadas, por trilhas nunca percorridas (CASTRO, et al., 1997), mas cetamente os olhares e contextos são outros. Em pleno século XXI, o olhar do fotógrafo difere-se completamente do olhar dos fotógrafos leigos do XIX, pois seu papel é o de um mediador cultural, possibilitando-o criticar o modelo em que vivemos.

Aqui encontra-se o ponto crucial da leitura das fotografias de Gênesis. Elas foram elaboradas durante o processo de modernização globalizante, isto é, após a superação das explorações geográficas marcadas pelo heroísmo da chamada Geografia Militante. Substituídas pelo turismo global, os mapas e as fotografias se tornaram imagens corriqueiras nas páginas dos jornais e imprescindíveis em nossas viagens aos pontos turísticos ao redor do mundo, fator que Driver vê como sobrevida da geografia militante na cultura popular (DRIVER, 2003). Isto significa dizer que os dias de glória dos exploradores se foram, mas passaram a ser mais frequentes no senso jornalístico, onde o heró́smo tornou-se comum, como nosso pão diário (CONRAD, 1923, apud DRIVER, 2003, p.199). 
Assim, se o homem pós-moderno está fadado a viver numa superfície entediante, fechada, completamente explorada, repleta de imagens banalizadas, ler a fotografias de Sebastião Salgado com olhos críticos é elevá-las a um patamar que está para além da suposta verdade presente em suas imagens. Reter o mundo inteiro em nossa mente, como uma antologia de imagens (SONTAG, 2004) que não necessita ser questionada só colabora para percebermos que o horizonte mundial é bem aceito na teoria, mas na prática é rejeitado (LOWENTHAL, 1961) e isto é perceptível quando resumimos o mundo em estereótipos banais, por exemplo.

$\mathrm{Na}$ verdade, a carreira marcadamente política de Sebastião Salgado que se debruçou a registrar a fome, a miséria e as migrações humanas nos impele a ler Gênesis como uma crítica ao modelo capitalista e suas consequências e não apenas sob a ótica de uma homenagem à Terra.

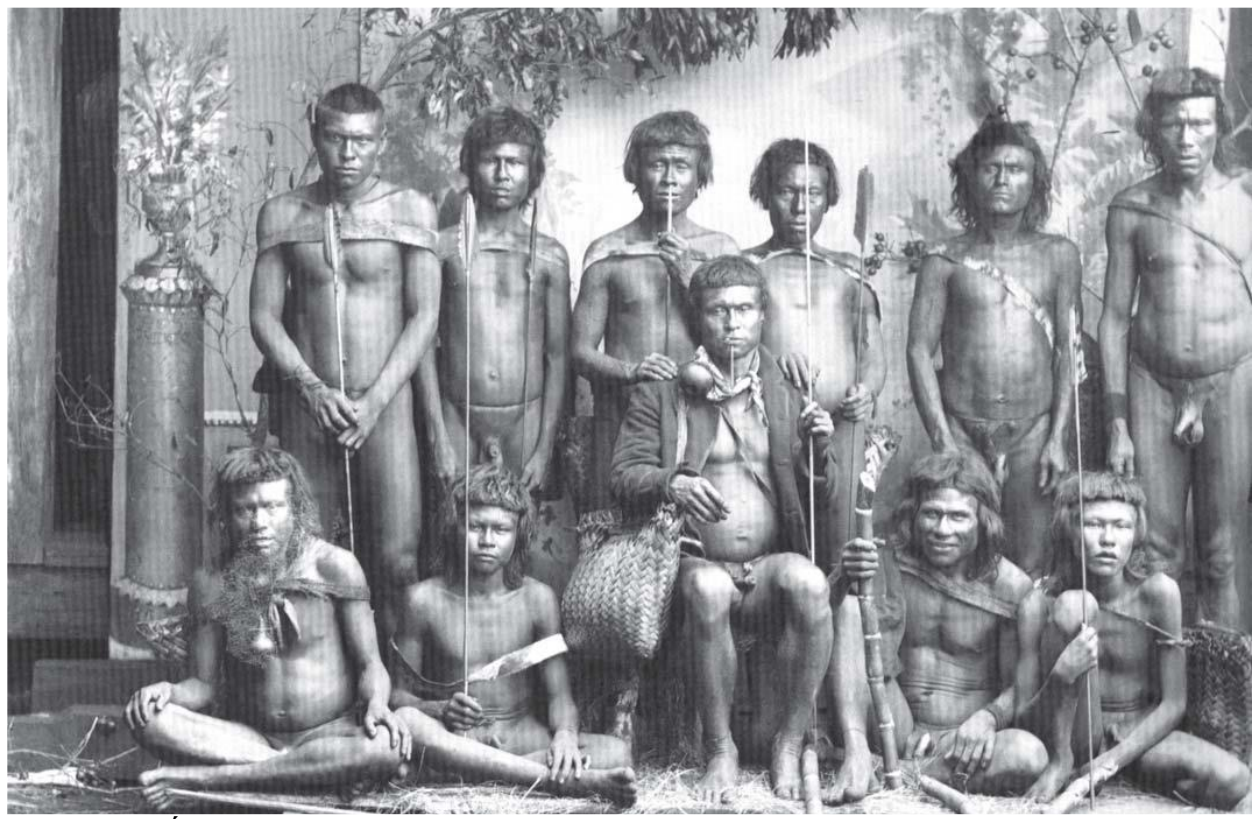

Figura 01. Índios bororo, 1880.

Fonte: Marc Ferrez (Coleção Gilberto Ferrez, Acervo Instituto Moreira Salles). Retirada de Tacca, 2011. 


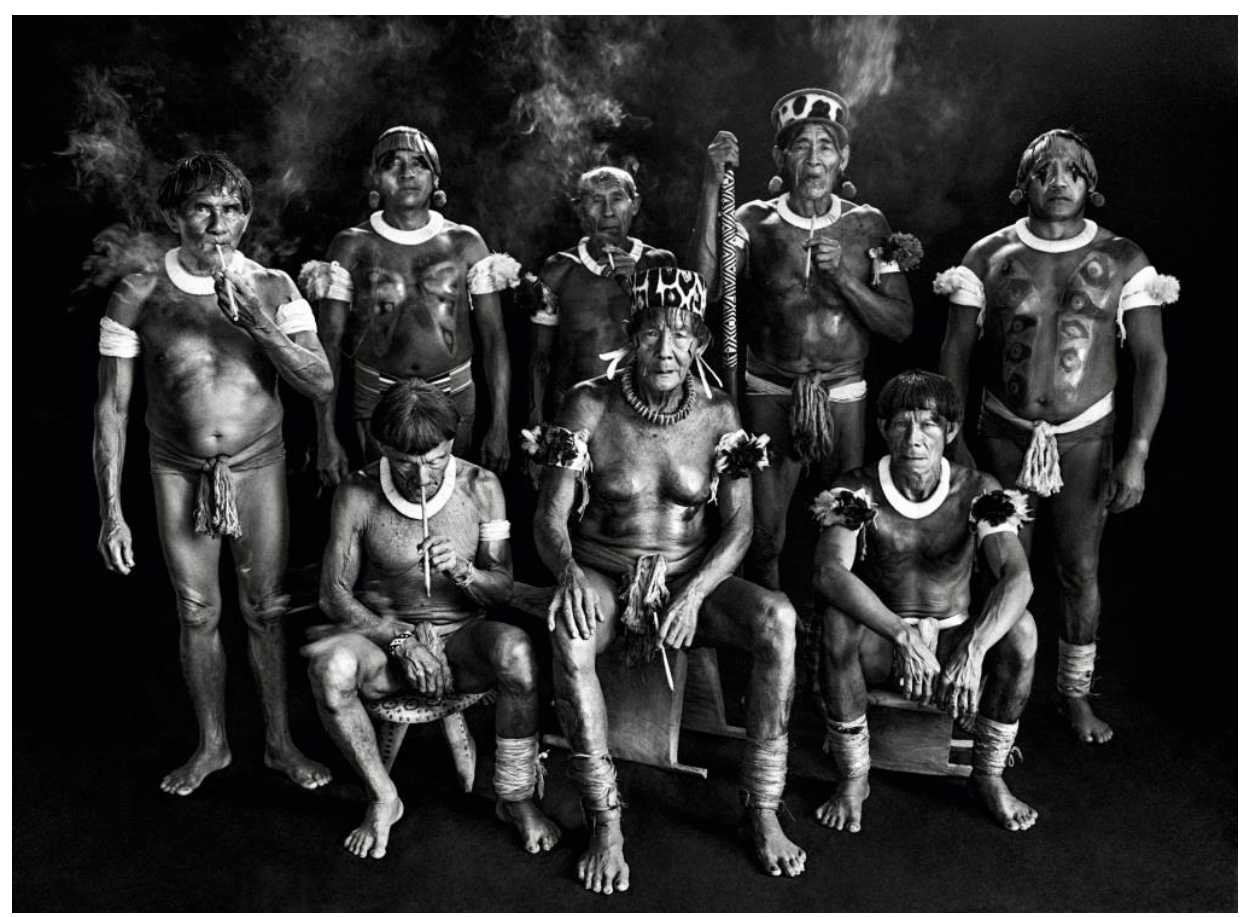

Figura 02. Xamãs da tribo Kamayura. Mato Grosso, região do Xingu. Brasil, 2005. Fonte: Sebastião Salgado. Gênesis, 2013.

Sintetizando, o objetivo do fotógrafo do século XXI não é renovar o velho mundo, muito menos buscar terras incógnitas. A propósito, as terras incógnitas em sentido absoluto não existem mais, assim como tampouco há terra absolutamente cógnita (WRIGHT, 1947). O que há é o empenho em encontrar novas formas de vê-las (CASTRO, 1997). Evidentemente, com os avanços nos estudos das imagens nos últimos anos, não podemos ver as fotografias como verossimilhança, verdade inquestionável. As imagens devem ser lidas para além do visual, atentando para os discursos do fotógrafo e compreendendo-o como um mediador cultural. Nesse sentido, a advertência mais evidente de Salgado está em notarmos que modificamos tanto o meio em que vivemos que sua viagem é uma corrida para registrar as paisagens, os animais e as etnias praticamente intocadas. Um convite para repensarmos nosso modo de produção e nossa forma de viver numa tentativa de resgatar parte de nossos elos históricos.

Apesar dessas intenções declaradas por Sebastião Salgado em palestras, entrevistas e também no livro autobiográfico "Da minha terra à Terra", para Susan Sontag, a busca em renovar o velho mundo e os velhos olhares sobre ele através da fotografia é um aspecto digno de pena, quixotesco, dessa atividade (SONTAG, 2004). Podemos dizer que quixotesco é também o resultado final da viagem de Sebastião Salgado: um álbum de fotografias de quase todos os continentes - exceto a Europa, 
conforme citado anteriormente - que visa apresentar o mundo à nós, tal como no início da prática fotográfica. Os álbuns resultantes das primeiras viagens de exploração visavam ser uma espécie de testemunho através do qual lugares distantes podiam ser observados e, assim, conhecidos por meio daquelas imagens que permitiam aos espectadores viajarem para lugares inóspitos.

Essa síntese do mundo elaborada por olhos e mentes europeus contribuiu para delinear os estereótipos que ainda hoje guardamos sobre os lugares, e Gênesis, um álbum que foi lançado mundialmente e apresentado em forma de exposição nas principais galerias e museus, acaba por reiterar essa visão de mundo europeia, ainda que elaborada por olhos de um latino-americano. Incorporado ao ciclo de pré-textos, itinerários e representações, as fotografias de viagem de Gênesis, tal como os primeiros álbuns, pode ser visto como parte integrante da construção de geografias imaginativas (SCHWARTZ, 1996).

\section{Considerações finais}

O movimento de fotografar e divulgar as imagens dentror do continente europeu tendia a reiterar os sentimentos de alteridade, haja vista que a formação da identidade é baseada na imagem do outro. O leitor era colocado no confortável papel de contemplador da diferença entre eles e os "não ocidentais". Seu exotismo atraía os cliques, fazendo deles algo digno de atenção, ainda que distante (LUTZ \& COLLINS, 1993: 2).

Ainda hoje as fotografias divulgam as diferenças culturais enquanto mantém e redesenha as fronteiras do imaginário geográfico e, consequentemente, do imaginário da sociedade. Essa dinâmica deve-se à maneira que a fotografia foi por muito tempo empregada, como verdade, forjando, validando, confirmando, moldando e perpetuando ideias de lugar, espaço, tempo, nós e o Outro. Trazer Gênesis à tona é perceber que existe uma crise de imaginários geográficos manifestada através do choque entre imaginários paisagísticos. Conforme visto anteriormente, a fotografia nos ilude, pois temos a impressão de que conhecemos o mundo por completo quando na realidade, a Terra inteira é simplesmente uma miscelânea de miniaturas de terrae incognitae, (WRIGHT, 1947) onde partes dos mundos particulares não são incorporadas em nossa antologia de imagens (SONTAG, 2004).

A obra de Sebastião Salgado constitui um material extremamente pertinente para pensarmos as fotografias e as formas de compreender os outros mundos, incluindo nossas relações com eles e nossas responsabilidades para com eles. Nesse movimento, há uma chance de nos libertar da universalização de nossos próprios paroquialismos, justamente porque necessitamos aprender a ir além das particularidades, a falar sobre questões maiores sem diminuir a significação dos lugares e das pessoas a que se destinam. E, assim, ampliando e examinando as nossas imaginações geográficas, poderemos perceber não só que nossas vidas estão radicalmente entrelaçadas com as 
vidas do Outro, mas também que temos uma responsabilidade contínua e inevitável com este (GREGORY, 1994).

Além disso, os objetivos de Gênesis estão em concordância com a realidade do século XXI: há uma corrida, por assim dizer, para manter ao menos em nossas memórias e em papéis de fotografia as etnias e a natureza que serão, muito provavelmente, devastadas pelo rolo compressor da máquina capitalista. Na verdade, não é novidade esta imcumbência dos fotógrafos. As câmeras começaram a duplicar o mundo justamente no momento em que a paisagem humana passou a experimentar um ritmo vertiginoso de transformação: enquanto uma quantidade incalculável de formas de vida biológicas e sociais é destruída em um curto espaço de tempo, um aparelho se torna acessível para registrar aquilo que está desaparecendo (SONTAG, 2004). E mais: os fotógrafos não só se atribuíram da tarefa de registrar o mundo em via de desaparecer como foram empregados com esse fim por aqueles mesmos que apressavam o desaparecimento.

O periódico The National Geographic Magazine desde a sua criação contou com fotografias de natureza, etnias e animais em matérias e álbuns, contudo, segundo Baitz (2005), as imagens de paisagem mostradas nos volumes da referida revista traziam a transformação da paisagem como via de desenvolvimento para fazer frente às potências europeias. Suas páginas revelavam gráficos estatísticos com a quantidade de matéria-prima presente na região tratada, justificando o tema como relevante.

Vale ressaltar que isto ocorre também com Sebastião Salgado. Dentre muitos patrocínios importantes, encontra-se a Vale, mesma empresa que devastou sua cidade natal e que levava o nome do rio que corta a região, o Rio Doce. O famigerado acidente ambiental em novembro de 2015, provocado pelo vazamento de rejeito da mineradora Samarco Mineração S.A., controlada pela BHP Billiton e pela Vale S.A. gerou críticas recorrentes ao fotógrafo. Questionado sobre a polêmica, Sebastião Salgado disse entender as preocupações dos ambientalistas em relação a empresas como a Vale, mas afirmou que "o problema não são companhias de mineração ou as petrolíferas, mas sim o sistema de vida que nós criamos"

É notório que a fotografia não se encerra nem se inicia nela mesma. Como visto, a fotografia revelou-nos o mundo, tornando-o passível de ser descoberto por um número cada vez maior de pessoas. O apuramento dessa linguagem visual acabou por servir de base à construção de um imaginário geográfico, principalmente a partir do aumento de sua circulação. Contudo, também foi evidenciado através de Gênesis que as representações não devem se fechar nas formas representadas (COSTA, 2014), vide as discussões plurais que podem surgir a partir da tentativa de interpretação das entrelinhas do trabalho do fotógrafo brasileiro Sebastião Salgado.

Como ciência imagética, cabe aos geógrafos olhar além da máscara da neutralidade documental (SCHWARTZ, 1996) para explorar as maneiras pelas quais as 12 Disponível em: [http://www1.folha.uol.com.br/ilustrada/2013/07/1313489-museu-e-criticado-por-aceitar-
financiamento-da-vale-para-mostra-de-sebastiao-salgado.shtml] Acesso em: julho de 2016 . 
fotografias, sobretudo as de viagens, serviram para conquistar o espaço e consagrar diferenças culturais.

\section{Referências Bibliográficas}

ALLEN, J. L. Lands of Myth, Water of Wonder: The Place of Imagination in the History of Geographical Exploration. In: LOWENTHAL, D.; BOWDEN, M. (eds): Geographies of the Mind: Essays In Historical Geosophy. New York and Oxford. Oxford University Press, 1971.

ALPERS, S. Arte de Descrever: A Arte Holandesa no Século XVII. Edusp, 1999.

BAITZ, R. Fotografia e Nacionalismo: A Revista The National Geographic Magazine e a construção da Identidade Nacional Norte-americana (1895-1914). Revista de História da Universidade de São Paulo, n. 153, 2005.

BESSE, J. Ver a Terra: seis ensaios sobre a paisagem e a geografia. São Paulo: Perspectiva, 2006.

BORGES, M. E. L. História \& Fotografia. 2a ed., Belo Horizonte: Autêntica, 2008.

BRIZUELA, N. Fotografia e Império: paisagens para um Brasil moderno. $1^{\mathrm{a}}$ ed. São Paulo: Companhia das Letras; Instituto Moreira Salles, 2012.

CASTRO, I.; GOMES, P. C.; CORRÊA, R. L. (orgs.). Explorações Geográficas: percursos no fim do século. Rio de Janeiro: Bertrand Brasil, (2012 [1997]).

CLAVAL, P. A paisagem dos geógrafos. In: CORREAA, R. L., ROSENDAHL, Z. (orgs.). Geografia cultural: uma antologia. Volume I. Rio de Janeiro: EDUERJ (2012 [2004]).

COSGROVE, D. Mundo de significados: geografia cultural e imaginação. In:

CORRÊA, R. L., ROSENDAHL, Z. (orgs.). Geografia cultural: uma antologia. Volume I. Rio de Janeiro: EDUERJ, (2012 [1994]).

COSGROVE, D.; DELLA DORA, V. High places: cultural geographies of mountains and ice. IB Tauris, 2008.

COSTA, E. Paisagem-memória e função social da fotografia. In: Geografia e Fotografia: apontamentos teóricos e metodológicos. Brasília: LAGIM, 2014.

DRIVER, F. Scientific exploration and the construction of geografical knowledge: Hints to Travellers. Finisterra, XXIII, n. 65, 1998.

DRIVER, F. Geography militant: cultures of exploration and empire. London: Blackwell Publishers, 2003.

FLUSSER, V. Filosofia da caixa preta: ensaios para uma filosofia da fotografia. São Paulo, Annablume (2011 [1983]). 
GREGORY, D. Geographical Imaginations. Cambridge/Massachusetts: Blackwell Publishers, 1994.

LATOUR, B. Cognição e visualização. Terra Brasilis (Nova Série) [Online], n.4, 2015. Disponível em: [https://terrabrasilis.revues.org/1308]

LIRA, L. A imagem do território na pintura de paisagens. Revista Espaço e Cultura, Uerj, RJ, n. 29, 2011.

LOWENTHAL, D. Geografia, experiência e imaginação: em direção a uma nova epistemologia geográfica. In: CHRISTOFOLETTI, A. (org.) Perspectivas da geografia. São Paulo: Difel, 1982.

LUTZ, C.; COLLINS, J. Reading National Geographic. University of Chicago Press, 1993.

MAYA, E. E. Nos passos da história: o surgimento da fotografia na civilização da imagem. Discursos fotográficos, v. 4, n. 5, p. 103-129, 2008.

NOGUÉ, J. Intervención en imaginarios paisagísticos y creación de identidades territoriales. In: LINDÓN, A.; HIERNAUX, D. (orgs.) Geografías de lo imaginário. Barcelona: Anthropos Editorial; México: Universidad Autónoma Metropolitana. Iztapalapa, 2012.

RAMÓN, M.; NOGUÉ J. Colonialismo, imperialismo y exploración en geografía: nuevas apontaciones críticas sobre orientalismo y postcolonialismo. In: NOGUÉ, Joan y VILLANOVA, José Luis (Eds.). España en Marruecos (1912-1956). Discursos geográficos e intervención territorial. Editorial Milenio, 1999.

RYAN, J. Photography, visual revolutions and Victorian Geography. In: LIVINGSTONE, D.; WITHERS, C. (edited by). Geography and revolution. Chicago e London: The University of Chicago Press, 2005.

RYAN, J. Picturing Empire: Photography and the visualization of the British Empire. Chicago: Reaktion Book, 1998.

SAID, E. Orientalismo. O Oriente como invenção do Ocidente. São Paulo: Cia. das Letras (2007 [1978]).

SALGADO, S; FRANCQ, I. Da minha terra à Terra. Tradução: Julia da Rosa Simões. $1^{\mathrm{a}}$ Ed. São Paulo: Paralela, 2014.

SALGADO, S; ANDIÓN, M. L. Outras Américas. Universidad de Santiago de Compostela, Vicerrectorado de Política Cultural, 1992.

SALGADO, S. Gênesis. Colônia: Taschen, 2013.

SALGADO, S. Trabalhadores. Uma arqueologia da era industrial. São Paulo: Companhia das Letras, 1993

SALGADO, S. Exodos. São Paulo: Companhia das Letras, 1999. 
SCHWARTZ, J. The Geography Lesson: photographs and the construction of imaginative geographies. Journal of Historical Geography, n. 22, v. 1, 1996.

SONTAG, S. Sobre Fotografia. São Paulo: Cia. das Letras, 2004.

TACCA, F. O índio na fotografia brasileira. História, Ciências Sociais e Saúde Manguinhos, Rio de janeiro, v. 18, n. 1. 2011.

WRIGHT, J. K. Terrae Incognitae: the place of the imagination in geography. Annals of the Association of American Geographers. V. XXXVII, n. 1, 1947.

\section{Filmografia}

SALGADO, J; WENDERS, W. O Sal da Terra. França, Brasil e Itália: Décia Filmes, Amazonas Images, Solares Fondazione dele Arti, 2015. 110 min. Disponível em: [https://vimeo.com/128242266]

Lara D’Assunção dos Santos

Doutoranda em Geografia pela Universidade do Estado do Rio de Janeiro (PPGEOUERJ), bolsista da Coordenação de Aperfeiçoamento de Pessoal de Nível Superior (CAPES) e integrante do Laboratório de Geografia, Imagem e Educação coordenado pelo prof. Dr. André Reyes Novaes. Mestre pela mesma universidade e graduada em Geografia pela Universidade Federal Rural do Rio de Janeiro (UFRRJ).

Rua São Francisco Xavier, 524, $4^{\circ}$ andar - Sala 4019 - Bloco B. Maracanã, Rio de Janeiro, RJ.

E-mail: larad.assuncao@gmail.com

Recebido para publicação em janeiro de 2017 Aprovado para publicação em março de 2017 